Joanna Goszczyńska (D) https://orcid.org/0000-0003-3804-4845

Instytut Slawistyki Polskiej Akademii Nauk

joanna.goszczynska@uw.edu.pl

\title{
Przewodnik „przewrotny” dla nieco bardziej wtajemniczonych
}

\section{(Jiří Gruša, Czechy. Instrukcja obstugi, tłum. A.S. Jagodziński, Międzynarodowe Centrum Kultury, Kraków 2018, ss. 298)}

\section{A "Subversive" Guidebook for Those More in the Know}

W jednym z końcowych rozdziałów przewrotnego, jak go nazwałam, przewodnika, osnutego wokół dramatu Franza Grillparzera Szczęście i upadek króla Ottokara znajduje się fragment, który wiele mówi o sposobie opowieści austriackiego autora, a zarazem świetnie pasuje do typu narracji samego Jiřego Grušy:

Wszystko kręci się wokół dwóch królowych, podstarzałej Margaret, z której staje się Ofelia, i przepięknej Kunhuty, z której jest megiera. Przemysła uwodzi Hybris dama od wszelkich katastrof. Grillparzer nie mówi o Czechach, lecz o końcu władców, którym pycha uderzyła do głowy. Nie wysławia żadnych Habsburgów, lecz tylko sophrosýne - umiejętność rozwagi, poczucie umiaru. Dlatego nawet na końcu jego sztuki, kiedy frenetycznie wrzeszczy się „Z Rudolfem na wieczne czasy!”, nie chodzi wcale o rytuał poddaństwa. Autor wie, że w polityce wieczność jest kadencyjna, a w dramaturgii oznacza ona aktualność postaci (s. 268).

Po tej nieco aluzyjnej zapowiedzi konwencji, w jakiej utrzymana jest instrukcja obsługi Czech autorstwa Grušy, gdzie często słowa znaczą więcej niż z pozoru znaczą, gdzie głębsze sensy ukryte są pod powierzchnią błyskotliwej, czasami gawędziarskiej narracji, przejdźmy do kilku podstawowych informacji. Jiří Gruša (1938-2011), sygnatariusz Karty 77, współzałożyciel (razem z Ludvíkiem Vaculíkiem) pierwszego niezależnego wydawnictwa „Petlice” (Skobel), wielokrotnie więziony za swoją działalność dysydencką, jeden z ciekawszych 
pisarzy czeskich XX wieku, w Polsce do popularnych nie należy. Przyćmiła go sława Bohumila Hrabala, Milana Kundery, Josefa Škvoreckiego, a ostatnio, za sprawą książki Aleksandra Kaczorowskiego, Oty Pavla. Do polskiego czytelnika trafił tylko jeden utwór w przekładzie Piotra Godlewskiego, wydany w niezależnym obiegu w 1989 roku, Kwestionariusz, czyli modlitwa za pewne miasto i przyjaciela. Wypełnić tę lukę stara się obecnie Andrzej Jagodziński, tłumacz niniejszego intrygującego przewodnika, który przygotowuje przekłady kolejnych tekstów czeskiego pisarza.

Zanim przejdę do omówienia, dwa słowa jeszcze na temat kontekstu powstania książki. Czechy. Instrukcja obstugi jest jedną z ponad 70 pozycji tworzących serię nietypowych przewodników wydawanych w monachijskiej oficynie Piper. O ich nietypowości decyduje fakt, że rządzą się prawami eseistyki historycznej i historyczno-literackiej i pisane są przez znanych pisarzy. Jest zatem książka Grušy raczej wybiórczym przewodnikiem po czeskiej kulturze i historii niż tradycyjnym przewodnikiem po kraju i jego zabytkach. Adresowana jest też niewątpliwie do - chciałoby się powiedzieć po hrabalowsku „starszych i zaawansowanych”. A zatem do odbiorcy, któremu czeska kultura nie jest zupełnie obca. Do takiego, który może w pełni rozkoszować się intelektualną ucztą, jakiej mu dostarcza błyskotliwy tekst.

Wyróżnić w nim można kilka kręgów tematycznych, stanowiących wprawdzie odrębne całości, jednak na skutek stosowania ciągów skojarzeń, aluzji, aktualizacji zazębiają się one, tworząc w efekcie barwną, ale nie przypadkową mozaikę czeskiej kultury.

Wątek historyczno-mitologiczny, otwierający intelektualną wędrówkę po Czechach, zaczyna autor tradycyjnie, od legendy o praojcu Czech, który odkrył dla swojego plemienia „ziemski raj”. Raj ten (a ślad jego pozostał w czeskim hymnie) - i tu już wkracza autorska, aktualizująca interpretacja pradziejów okazał się, jak pisze Gruša, „europejskim korytarzem przechodnim”, ze wszystkimi tego negatywnymi konsekwencjami. Tego typu narracja zdominuje cały tekst: dowcipna, aluzyjna, erudycyjna, miejscami zabarwiona gorzką ironią, pełna dystansu do własnej historii i mentalności przedstawicieli własnego narodu.

W podobnym stylu i duchu utrzymany jest kolejny rozdział, będący swego rodzaju ciagiem dalszym wprowadzenia w meandry czeskiej kultury, zatytułowany Pochwała stereotypów. Lekko kpiarski, poświęcony zarówno autostereotypom, jak i czeskim stereotypom, zwłaszcza w odniesieniu do postrzegania innych narodów. Chciałoby się powiedzieć, że wątek stereotypowy właśnie, ale ważny, bowiem stereotyp będzie jednym ze słów kluczy, którym otwiera Gruša coraz to nowe obszary czeskiej kultury. Kolejnym będzie czeski język. To trzeci etap wprowadzenia do wędrówki (aczkolwiek wprowadzeniem nie nazwany), zawarty w rozdziale Daszki i pateczki, barwnej opowieści o specyfice czeskiego języka, która posłuży w późniejszych odsłonach opowieści o czeskiej kulturze do rozważań etymologicznych. Brzmią one przekonująco, czasami dowcipnie, potwierdzają błyskotliwą erudycję autora, aczkolwiek traktować je 
należy raczej w kategoriach zabawy, a nie naukowego wywodu. Idzie tu Gruša, może prześmiewczo, śladami Jána Kollára, który dopatrywał się słowiańskości $\mathrm{w}$ wielu niesłowiańskich nazwach, szukając tym samym potwierdzenia wielkości Słowiańszczyzny.

W tym nietypowym przewodniku rozdziałów jest w sumie 28 , trudno je zatem wszystkie szczegółowo omawiać. Teoretycznie ich kręgi tematyczne wyznacza przestrzeń, ale w gruncie rzeczy stanowi ona tylko pretekst do zgłębiania na ogół najbardziej reprezentatywnych obszarów czeskiej kultury. Kontynuacją wątku historyczno-mitologicznego jest opowieść o czasach Wacława IV, w której burzliwe losy króla przeplatają się z historią Jana Husa. Ta barwna opowieść, snuta na prawach eseistyki historycznej, z dygresjami i aluzjami do czasów późniejszych, potwierdza krytycyzm autora, jego „cięty język”, umiejętność demitologizowania ważnych ogniw narodowej historii, odbrązowiania jej aktorów i trzeźwego patrzenia również na czeskie „tu i teraz”.

W ten wątek wpisuje się także utrzymana w tonacji pół żartem, pół serio opowieść o Janie Nepomuku - z Janem Husem i królem Wacławem (a także św. Wojciechem) w tle. A pretekstem do niej jest dotarcie w wędrówce po Morawach do miasteczka Nepomuk. Staje się też ono punktem wyjścia do opowieści należącej do drugiego kręgu, literackiego, której bohaterem jest Josef Linda, współautor słynnych rękopisów - dziewiętnastowiecznych falsyfikatów, pozostający na ogół w potocznej narracji w cieniu drugiego autora, Václava Hanki. Jak pisze Gruša: „Václav szybował w obłokach kariery, a Josef opadał ku ziemi niby ptak zmęczony lotem. (...) Czekało go usychanie, a na Hankę - pomniki” (s. 113). To kolejny przykład weryfikowania przez Grušę podręcznikowej wersji z pozoru mało istotnego ogniwa czeskiej literatury, które zainspirowało fundamentalny spór o sens czeskich dziejów. Bohaterem tego rozdziału jest bowiem nie tylko Linda, ale także same rękopisy.

Krąg portretów literackich jest dosyć szeroki. Ich wybór ponownie można uznać za stereotypowy, czego jednak nie należy traktować w kategoriach zarzutu, skoro czytelnik dostaje do rąk tekst instruktażowy. Mamy zatem klasyków literatury dziewiętnastowiecznej, Josefa Kajetana Tyla, Boženę Němcovą, Karela Havlícka-Borovskiego (w tle pojawia się Karel Hynek Mácha i Jaromír Erben), Aloisa Jiráska oraz dwudziestowiecznej, Karela Čapka i Jaroslava Haška. Spod płaszczyka gawędziarskiej narracji wyłania się wnikliwa ocena klasycznych dzieł czeskiej literatury, a także mniej znane, czasami nieco pikantne epizody z biografii ich twórców. To, co najbardziej w tych opowieściach fascynuje, to erudycyjna aluzyjność, łączenie postaci i miejsc, przywoływanie faktów z odległej przeszłości i ich wpisywanie w diagnozę współczesności. Na przykład przy okazji twórczości Jiráska autor nie tylko porusza kwestię inspiracji czeskiej literatury kulturą i literaturą niemiecką, problem owego „zwierciadlanego odbicia”, o którym pisał swego czasu Vladimír Macura ${ }^{1}$ (niemieckie inspiracje pojawiają

V. Macura, Znameni zrodu, Praha 1995. 
się też w kontekście literatury dla dzieci), nie tylko kwestię mitotwórczej roli, jaką odegrały jego powieści w okresie tak zwanego odrodzenia narodowego, ale pisze także o wpływie tego autora, nota bene porównywanego najczęściej z Henrykiem Sienkiewiczem, na czeskie życie po drugiej wojnie światowej. „)irásek konstatuje Gruša - pasował komunistom jako konstruktorom raju na ziemi" (s. 203). I dodaje, że dzięki trwającemu 40 lat systemowi edukacji do dziś można znaleźć tego pogłosy w pochwale samoograniczenia czy strachu przed innością. Z kolei w wątku czapkowskim, poświęconym głównie młodszemu z braci Čapków, Karelowi, jako temu, który „stał się pierwszym czeskim autorem, który przekroczył cień Czech” (s. 207), znalazło się miejsce na przywołanie jego relacji z prezydentem Tomašem G. Masarykiem, ale nie zabrakło też uszczypliwości pod adresem Edvarda Beneša, jako tego, „który uciekł na emigrację" (s. 211). O ile Masaryk postrzegany jest przez Grušę jako prawdziwy mąż stanu, o tyle ocena Beneša pozostaje kontrowersyjna. Po śmierci Masaryka - pisze Gruša - „zamiast profesora przyszedł asystent. Siedział na Zamku i nawet z podzamcza było widać różnicę" (s. 211).

Losy braci Čapków - bo i dla Josefa, pozostającego tradycyjnie w cieniu brata, aczkolwiek ostatnimi laty coraz bardziej docenianego, zwłaszcza w kontekście badań nad pokrewieństwem sztuk, znalazło się nieco miejsca - wpisane są w przestrzeń Pragi. Staje się też ona pretekstem i kontekstem do snucia dwóch jeszcze fascynujących opowieści. Jedna poświęcona jest burzliwym losom Mileny Jesenskiej (to rozdziały Piękna i bestia oraz Piękna i Gtupi Jasio) z Franzem Kafką i atmosferą międzywojennej Pragi w tle, druga będąca gorzką refleksją nad własnymi doświadczeniami autora, przynosi zarazem podskórną diagnozę czeskiej rzeczywistości lat pięćdziesiątych, a potem okresu tak zwanej normalizacji (Praga szara ..., ... i Ztota). Wątek autobiograficzny przeplata się tu z aluzjami historycznymi, miejscami fakty przebijają powłokę metaforyczności, odsłaniają owo „drugie dno”, nienazwane wprost, które skrywa losy intelektualistów dysydentów.

W wędrówce po obszarach literackich znalazła się również literatura dla dzieci. W kilku odsłonach pojawia się znany nam Rumcajs, ale też inni bohaterowie klasycznej czeskiej dziecięcej literatury (na przykład Mrówka Ferda). W wyrafinowany sposób pokazane są wspominane już pokrewieństwa z pierwowzorami niemieckimi. Ale nie tylko to. Tu także dywagacje o literaturze prowadzą do stwierdzeń o charakterze uniwersalnym, ale zarazem z wyraźnym odniesieniem do kontekstu czeskiego.

Panorama kultury nie byłaby pełna, gdyby zabrakło w niej muzyki. Do wątku mitologicznego nawiązuje Gruša w opowieści o słynnym kompozytorze Antonínie Dvořáku i Jaroslavie Kvapilu, autorze libretta do opery Rusatka, postrzeganej przez autora w kategoriach czeskiej sagi, a nie patriotycznej idylli (s. 168), która zyskała światową sławę. W Sprzedanej narzeczonej Bedřicha Smetany dostrzega wymiar podwójnej czeskości, wspominając kontrowersyjną biografię librecisty Karola Sabiny, który z rewolucjonisty roku 1848 stał się 
austriackim agentem. Jego los posłużył Grušy do cierpkich dywagacji o uniwersalnym charakterze. Kreśli też losy kompozytora „odrzuconego” Bohuslava Martinů i trudną drogę do sławy Leoša Janáčka. Również te rozdziały, wielowarstwowe w swojej semantyce, na kanwie losów wybitnych kompozytorów odsłaniają złożoność ówczesnej sytuacji w monarchii.

Atrakcyjność książki to także zasługa bardzo dobrego przekładu, oddającego niuanse gruszowskiej narracji. Bardzo rzadko miałam pokusę, żeby zajrzeć do oryginału, a jeśli już, to nie dlatego, aby sprawdzić adekwatność przekładu, ale żeby zobaczyć, co kryje się za propozycją tłumacza. Polemizowałabym z jednym tylko twierdzeniem Jagodzińskiego, który jest zarazem autorem posłowia-komentarza, „że książka spełnia też niemal wszystkie wymogi świetnego przewodnika” (s. 288). Oczywiście Gruša stara się poruszać w swoich rozważaniach po pewnej wyznaczonej trasie, wiąże regiony, miasta, miasteczka z losami urodzonych w tych miejscach ludzi bądź z rozgrywającymi się tu wydarzeniami. Ale jest to raczej pretekst, bowiem w gruncie rzeczy bardziej fascynuje go fenomen czeskiej kultury, jej jasne i ciemne strony, wkradanie się w zakamarki czeskiej mentalności.

Książka, jak przypomina tłumacz, napisana została pierwotnie po niemiecku, jej sukces wygenerował czeską wersję, która miała kilka wydań, sukcesywnie uzupełnianych, by wreszcie osiągnąć przygotowane przez autora „wydanie kanoniczne". I ono właśnie trafia do polskiego czytelnika. 